\title{
Does managerial bias pose destructive impact on company? A non-linear relationship between CEO's overconfidence and company value
}

\author{
Bayu Wiratama ${ }^{1}$, Kris Brantas Abiprayu², and Siti Ridloah³ \\ 1,2,3 Management Department, Faculty of Economics, Universitas Negeri Semarang, Indonesia
}

\begin{abstract}
This research aims at testing the influence of CEO's overconfidence (KDB) on the values of companies registered with the Indonesian Stock Exchange in the period 2007-2015. $\mathrm{KDB}$ is a bias inherent in individual, particularly corporate CEO resulted from his/her great authority. A CEO with KDB will assume that his/her company has investment opportunities in the future and, thus, reduce dividend in anticipation of acquiring an investment opportunity in the future. Some opinions argue that KDB's benefit will be maximal when the confidence is at moderate level. A manager is deemed able to contribute to his/her company, have a good innovation level, have optimal motivation level, and present lower level of cost of debt or capital and optimal amount and rate of investment return. Too low or too high KDB is deemed only to pose negative impact on company value as resulted from non-optimal degree of leverage and investment.
\end{abstract}

Keywords overconfidence (KDB); CEO; investment; company value

\section{INTRODUCTION}

Behavioral finance starts from a psychological field highlighting that an individual cannot make a decision without his/her psychological condition influence, and that individual is assumed to have limited rationality (Shefrin, 2001). Many empirical studies related to financial-based-psychology emerge later confirming doubt on the traditional financial concept and doubt on theories underlying the traditional finance like the efficient market hypothesis (Baker, Ruback, \& Wurgler, 2004).

One of the most intensively discussed topic in behavioral financial studies is the overconfidence (KDB) behavior in corporate strategic decision. Literatures in the field of psychology report that individuals basically have the same characteristics, in which they tend to be overconfident and optimistic (Hackbarth, 2008). Individuals will be deemed to be overconfident when they believe that any information and capabilities they have are sufficient to predict future, and consequently believe that any decision they make now may pose positive results in the future. The results of experimental researches conducted by Kruger (1999), Svenson (1981) state that individuals with positive characters will perceive themselves "above average".

In corporate context, manager is individual exposed the most to bias like KDB ( $\mathrm{Li}$ and Tang, 2010). There are some reasons that corporate manager bear KDB. First, an individual will be very confident when he/she perceives that he/she has a strong control over outcome (Langer, 1985). Second, an individual will also be susceptible to the tendency to judge or predict an outcome too high (overestimate) when he/she is highly committed to its achievement (Weinstein, 1980). Third, an individual will overestimate his/her own ability when he/she hardly find any direct comparison of a decision he/she makes. The consequences of this bias are to have a high level of loss aversion, to perceive that the company he/she leads is in undervalued condition, to tend to make overinvestment using internal fund, or to prefer debt to equity (Ben-David, Graham \& Harvey, 2007; Shefrin, 2001).

\section{LITERATURE REVIEW AND HYPOTHESES DEVELOPMENT}

In the scope of behavioral finance, a CEO with managerial bias perceives that his decision making will maximize company value, although the opposite actually takes 
place (Baker et al, 2004). In research domain, economic losses suffered by company because of managerial bias remain unclearly quantified (Baker et al, 2004; Fairchild, 2009). Similarly, no many empirical results have proven the effects of CEO's KDB on company value, but only few researches have tested both variables.

Gervais and Goldstein (2004) and Fairchild (2009) are of the opinion that CEO's KDB may drive company productivity. However, models tested by other researchers show that CEO's irrational behavior causes overinvestment which lead to reduction of marginal value created by the investment, and the tendency of CEO funding investment using debt, leading to company's distress cost (Hackbarth, 2009; Heaton, 2002; Malmendier \& Tate, 2005a).

The research therefore is of the opinion that this bias will influence the quality of manager's decision in relation to corporate policy. Therefore, further test is necessary to examine whether this bias benefits or damage company instead. Managerial bias like KDB may influence corporate policy, including funding decision, investment decision and dividend decision which will eventually influence company's performance.

Malmendier and Tate (2005a, 2005b) and Malmendier et al. (2011) test the influence of managerial bias on corporate policy. They find that manager with KDB will show three tendencies: first, overinvestment; second, tendency to perform merger and acquisition which do not give added value to company; and, third, tendency to use debt instead of issuing capital.

Ben-David et al. (2007) test the influence of CEO,s overconfidence on corporate policy using survey. They find that company led by manager with high level of confidence will have high investment level, often perform acquisition, have high rate of debt, infrequently distribute dividend and prefer share repurchase.

Campbell et al. (2011) test the influence of managerial trait on company owner's prosperity, and this research is the first one to test the relationship of both. They test the model formulated by Goel and Thakor (2008), in which the model predicts that manager with moderate-level overconfidence will more optimally maximize company performance which will eventually lead to company owner's prosperity. This takes place since manager with normal confidence tends to appropriately catch information, without exaggerating or reducing the quality of information he/she has. This research result is consistent with the research conducted by Hackbarth (2008) predicting that managerial bias will remain posing positive impacts on shareholders as long as it remains at normal or moderate level.

Campbell et al. (2011) in their research test and prove a statement that manager with overconfidence will be likely to be dismissed from his/her job, since such a manager often exaggerates the quality of any information, which lead to overinvestment and may eventually devastate company value. Manager too low confidence will also tend to highly doubtful which may lead to his/her dismissal since he/she tend to make underinvestment which eventually lead to company's slowed down productivity. Manager deemed to improve company value is one with moderate level of confidence. This argument is consistent to the research conducted by Heaton (2002), Goel and Thakor (2008), and Hackbarth (2008).

The research considers that CEO's confidence is trade-off with benefits it brings out to influence company value. Therefore, this research will prove the impacts of CEO's $\mathrm{KDB}$ on company value.

The problem of this research is to examine whether there is negative impacts of CEO's too low KDB and CEO's KDB on company value in comparison to moderate confidence. The purpose of this research is to test that CEO's too low KDB and CEO's too high KDB will pose negative impact on company in comparison to moderate confidence.

H1: CEO's KDB positively affects the company value.

\section{METHODS}

The population of this research is all stocks of companies which go-public and are registered with the Indonesian Stock Exchange during the research period, from 2007-2015. This research takes all companies included in the defined criteria as its samples.

The proxy of company value is Tobin's $Q$ in accordance with Malmendier and Tate's model (2005). Tobin's Q is defined as asset market value divided by asset book value. Asset market value is obtained from total assets plus equity market value reduced by equity book value. Equity market value is 
Table 1.

Descriptive Statistics

\begin{tabular}{cccccc}
\hline Variable & N & Mean & Dev. St. & Min & Max \\
\hline Q & 265 & 1.421 & 1.478 & 0.003 & 6.202 \\
KDB & 327 & 0.1000 & 0.3000 & 0 & 1 \\
LOW_KDB & 327 & 0.052 & 0.223 & 0 & 1 \\
HIGH_KDB & 325 & 0.468 & 0.499 & 0 & 1 \\
SIZE & 262 & 7.399 & 1.589 & 3.857 & 11.632 \\
PROF & 292 & 0.132 & 0.103 & -2.318 & 0.894 \\
LEV & 271 & 0.211 & 0.189 & -0.627 & 0.286 \\
\hline
\end{tabular}

total outstanding stocks multiplied by stock price at the end of year and equity book value is Total equity reduced by total preferred stock plus deferred tax (balance sheet)

This research's free variable has two CEO's KDB proxies to be used, which are one developed by Richardson (2006), and one used by Scrand and Zechman (2012). The proxies will be treated in separate interaction with company value as an attempt to test the robustnessof CEO's KDB proxies.

The proxy modeled by Richardson (2006) is used to view the investment level of a company in line with KDB measurement in this research. This is appropriate to the research conducted by Malmendier and Tate (2005) and Campbell et al (2011) stating that there is relationship between CEO's KDB and investment decision, theoretically or empirically. Therefore, we may make a simple conclusion that company's investment level contains information related to CEO's KDB.

The Richardson's model (2006) is as follows:

$\begin{aligned} \mathbf{I}_{\mathrm{NEW}, \mathrm{t}} & =\beta_{0}+\beta_{1} \text { Growth }_{\mathrm{t}-1}+\boldsymbol{\beta}_{2} \text { LeV }_{\mathrm{t}-1}+\beta_{3} \\ & \text { Cash }_{\mathrm{t}-1}+\beta_{5} \text { Size }_{\mathrm{t}-1}+\beta_{7} \mathbf{I}_{\mathrm{NEW}, \mathrm{t}-1}+ \\ & \sum_{\mathrm{i}=1}^{11} \alpha_{1 \mathrm{i}} \text { Industry }_{\mathrm{i}}+\sum_{\mathrm{j}=1}^{7} \alpha_{2 \mathrm{j}} \text { Year }_{\mathrm{j}}+\varepsilon\end{aligned}$

In which,

$\mathrm{I}_{\mathrm{NEW}, \mathrm{t}}$

$=\left(\right.$ Capex $_{\mathrm{t}}+$ Acquisition $_{\mathrm{t}}+$

$R \& D$ Expenses $s_{t}$-Sales

ofPPE $_{t}$ )- (Depreciation

\&amortization $\left.\mathrm{t}_{\mathrm{t}}\right)$

Growth = Tobin's $Q$ (market value/

book value of equity)

Lev $\quad=$ Ratio of total debt to total assets

Cash $\quad=$ In (cash + short-term investment)

Size $\quad=\ln$ (total assets)

$\mathrm{I}_{\mathrm{NEW}, \mathrm{t}-1} \quad=\mathrm{I}_{\mathrm{NEW}, \mathrm{t}}$ in the previous year

Industry, year = Dummy industry and year
From the regression model above, residual value will be obtained from each sample. Consistently to Richardson's (2006), sample companies which generate positive residue will be classified into overinvestment companies, while company samples with negative residue will be classified into underinvestment companies. Companies in overinvestmentcategory will be scored 1, assuming that they have $\mathrm{CEO}$ with $\mathrm{KDB}$, while companies in underinvestment category will be scored 0 .

According to Schrand and Zechman (2012), there are two indicators of KDBat firm-level related to investment decision and funding decision made by company, proven by previous empirical researches. Schrand and Zechman (2012) assume that if both indicators are fulfilled, a company will be assumed to have CEO with KDB. Therefore, KDB will be scored 1, and KDB will be scored 0 if both indicators are not fulfilled.

The first KDB component is industryadjusted excess investment (EXINVEST). This variable is measured using company's capital expenditure. A company will be stated to have CEO with KDB if its EXINVEST is above median industry for two consecutive years. If company's EXINVEST is above median industry, the EXINVEST will be categorized 1 , and 0 to the contrary. Score 1 indicates that a company has high KDB (High_KDB) and score 0 indicates low KDB (Low_KDB).

The second KDB component is firm's industry-adjusted debt-to-equity ratio (DERATIO). Heaton (2002) present a research result that $\mathrm{CEO}$ with $\mathrm{KDB}$ tends to follow pecking order theory. This result is consistent with the result of research conducted by Hackbarth (2008). A DER higher than median industry may illustrate CEO's overconfidence (Malmendieret al., 2011; Ben-David et al., 2007). DERATIO will be scored 1 if company's DER ratio is above median industry. Score 1 indicates that a 
Table 2.

CEO's KDB and Company Value

\begin{tabular}{|c|c|c|c|c|c|}
\hline Variable & Model 1 & Model 2 & Model 3 & Model 4 & Model 5 \\
\hline KDB & $\begin{array}{l}0.415^{\star \star \star} \\
(8.06)\end{array}$ & & $\begin{array}{l}0.346^{\star \star \star} \\
(8.01)\end{array}$ & & $\begin{array}{l}0.324^{\star \star *} \\
(2.45)\end{array}$ \\
\hline LOW_KDB & & $\begin{array}{l}-0.152^{*} \\
(-1.71)\end{array}$ & & $\begin{array}{l}-0.014^{*} \\
(-0.16)\end{array}$ & $\begin{array}{l}-0.06^{*} \\
(-1.35)\end{array}$ \\
\hline HIGH_KDB & & $\begin{array}{l}-0.376^{\star * *} \\
(-6.55)\end{array}$ & & $\begin{array}{l}-0.220^{\star \star *} \\
(-6.03)\end{array}$ & $\begin{array}{l}-2.61^{\star \star \star} \\
(-9.26)\end{array}$ \\
\hline SIZE & & & $\begin{array}{l}-0.118^{* * *} \\
(-5.65)\end{array}$ & $\begin{array}{l}-0.198^{* \star \star} \\
(-4.30)\end{array}$ & $\begin{array}{l}-0.088^{* \star *} \\
(-3.55)\end{array}$ \\
\hline PROF & & & $\begin{array}{l}5.89 * \star * \\
(12.91)\end{array}$ & $\begin{array}{l}5.234^{\star * *} \\
(12.18)\end{array}$ & $\begin{array}{l}5.505^{\star * \star} \\
(13.51)\end{array}$ \\
\hline LEV & & & $\begin{array}{l}-2.209^{* * *} \\
(-1.14)\end{array}$ & $\begin{array}{l}0.297^{*} \\
(-4.14)\end{array}$ & $\begin{array}{l}-0.370^{* * *} \\
(-2.32)\end{array}$ \\
\hline Constant & $\begin{array}{l}1.515^{\star \star *} \\
(42.17)\end{array}$ & $\begin{array}{l}1.588^{* \star *} \\
(41.21)\end{array}$ & $\begin{array}{l}1.597^{* * *} \\
(11.23)\end{array}$ & $\begin{array}{l}1.675^{\star * \star} \\
(9.65)\end{array}$ & $\begin{array}{l}1.609^{* * *} \\
(9.9)\end{array}$ \\
\hline Adj $R^{2}$ & 0.20 & 0.22 & 0.27 & 0.28 & -.28 \\
\hline Observation & 2255 & 2255 & 2254 & 2255 & 2255 \\
\hline
\end{tabular}

t statistics in parentheses ${ }^{*} p<0.1^{* \star} p<0.05^{* \star *} p<0.01$
company have high KDB (High_KDB) and score 0 indicates low KDB (Low_KDB).

The control variables employed in this research constitute ones deemed to have separate impact on company value,

Company size (SIZE), which in this research is measured using natural logarithm of company's total assets. These variables are expected to be negatively connected with dependent variables.

Profitability (PROF), which is the comparison between operating profit and total assets, expected to positively influence company value.

Leverage (LEV), which is total long-term debt compared with total equity, expected to negatively influence company value.

The model employed to test hypothesis 1 is logistic regression. The data constitute panel data. The model employed to test hypothesis 1 is as followed:

$$
\begin{aligned}
& Q_{i t}=\beta_{1}+\beta_{2} K D B_{i t}+\sum_{h=1}^{5} \gamma_{h} X_{h i t}+\varepsilon_{i t} \\
& Q_{i t}=\beta_{1}+\beta_{2} K D B_{i t}+\sum_{h=1}^{5} \gamma_{h} X_{h i t}+\varepsilon_{i t}
\end{aligned}
$$

In which,

$\begin{aligned} \mathrm{Q}_{\mathrm{it}} & =\text { Tobin, } \mathrm{Q} \\ \mathrm{KDB}_{\text {it }} & \text { Dummy variable CEO,s } \\ & \text { KDB obtained from } \\ & \text { overinvestment proxy, } \\ & \text { scored 1 if company is of } \\ & \text { overinvestment category, } \\ & \text { and scored } 0 \text { to the } \\ & \text { contrary. } \\ = & \text { Control variables SIZE, } \\ & \text { PROF, LEV }\end{aligned}$

\section{RESULTS AND DISCUSSION}

A summary of variables employed in this research is given in table 1 . This research's data are unbalanced panelobtained from 2007-2015. We may examine that the observations of each variable show different number since the researcher consciously adjust data deemed to cause statistical bias as the result of outlier data. Table 2 informs the relationship of CEO's KDB with company value proxied by Tobin's $Q$. No control variable is in interaction in the initial two models. We may observe that both models support the hypothesis presented in this research. CEO's KDB poses positive impact on company value and too low KDB and too high KDB pose negative impact on company value. Model 3 to model 5 include all control variables deemed to influence company value. With existing control variables, we expect to ensure that KDB's impact on company value is not influenced by any other variable which may lead to biased result. KDB variable generates consistent value in models 3 and 5, positively and significantly on company value, both in interaction with control variables and when model 5 is in interaction with KDB's variables. In LowKDB and High KDB variables, the results presented by models 4 and 5 are also consistent with that of model 2. Both low and high KDBs show negative value on company value. The one difference is only the significance level of LOW_KDB variable at alpha 0.1 .

The results shown by all control variables are as what the researcher has expected. Company size negatively and significantly 
influences company value. Company's big size is identical to company's maturity level, which means that big company is deemed to be mature, and its life cycle is deemed to be lower than that of developing or growing company, since a mature company is assumed not to have reinvestment opportunity (depleted). The profitability variable positively influences company value, and leverage negatively influences company value. The higher the leverage, a company will have higher debt cost, higher distress risk, higher total debt than its equity).

\section{CONCLUSION}

This research aims at testing the influence of CEO's overconfidence (KDB) on company value. Companies led by CEO with too high or too low KDB evidently have negative influence to their company value. CEOs with KDB tend to be "overconfident" of their ability to predict future, which in this case is future investment opportunity. This confidence puts a company in overinvestment condition with higher cost of debt since CEOs with higher KDB tend to prefer debt to equity. The use of debt makes company have high leverage level. The opposite takes place on CEO with too low KDB. Doubt makes existing investment opportunity, which should be taken by company, no taken which put company in underinvestment condition and slow down its productivity.

To test KDB, this research employs two proxies of Schrand and Zechman (2012) and Richardson (2006) symbolized as KDB1 and KDB2. These proxies usage is initially intended to test model robustness if two different proxies are used. However, some inconsistent results are found between both proxies during test. Although both proxies present the same results for hypothesis test, but some variables in some models are not the same, among others, significance level and mark of variable coefficient.

Some previous researches state that CEOs with KDB will argue that company will have future investment opportunity, thus they will reduce dividend for internal fund reserve. The tests performed in this research are still limited to testing that when a company have $\mathrm{CEO}$ with $\mathrm{KDB}$, there is a tendency that the company will distribute dividend lower than other companies led by rational CEO. However, this research is still unable to answer to what extent the future often assumed by CEO that the company has investment opportunity. It needs to test other KDB constructs, since there is no standard construct to measure an individual's overconfidence. One model will be found out of some tested KDB constructs to measure the most robust overconfidence.

\section{REFERENCES}

Allen, F., and Michaely, R.(2003). Payout policy. In: Constantinides, G.M., Harris, M., Stultz, R.M. (Eds.), Handbook of the Economics of Finance, Vol. 1. Elsevier, 337-429 (Chapter 7).

Baker, M., Ruback, R. S., and Wurgler, J. (2004). Behavioral corporate finance: A survey. Technical report, National Bureau of Economic Research.

Ben-David, I., Graham, J.R., Harvey, C.R. (2007). Managerial Overconfidence and Corporate Policies. Working Paper. Duke University.

Black, B. (2001). The corporate governance behaviour and market value of Rusian firms. Emerging Market Review, Vol. 2, 89-108.

Campbell, T.C., Gallmeyer, M., Johnson, S.A., Rutherford, J., and Stanley, B.W. (2011). CEOoverconfidence and forced turnover. Journal of Financial Economics, Vol. 101, 695-712.

Clarke, D., (2003). Corporate governance in China: An overview. China Econ. Rev, Vol. 14. 494-507.

DeFinetti, B. (1962). Does it make sense to speak of good probability appraiser? In I. J. Good (Ed.), The scientist speculates: An anthology of partly-baked ideas. London: Basic Books Inc.

DiMaggio, P., and Powell, W. (1983). The iron cage revisited: Institutional isomorphism and collective rationality in organizational fields. American Sociological Review, Vol. $48,147-160$.

Fairchild, R. L. (2009). Managerial overconfidence, moral hazard problems, and excessive life-cycle debt sensitivity. Investment Management and Financial Innovations, Vol 6 (3)

Finkelstein, S., and Boyd, B., 1998. How much does the CEO matter? The role of managerial discretion in the setting $C E O$ compensation. Academy of Management Journal, Vol. 41, 179-199.

Finkelstein, S., and Hambrick, D. (1990). Top management team tenure and organizational outcomes: The moderating role of managerial discretion. 
Administrative Science Quarterly, Vol. 35, 484-503.

Gervais, S, Heaton, J.B and Odean, T. (2003). Overconfidence, investment policy, and executive stock option. Rodney L. White Center for Financial Research Working paper

Gervais, S and Goldstein, I.(2004). Overconfidence and team coordination. Working paper, Duke University.

Goel, A.M., and Thakor, A.V. (2008). Overconfidence, CEO selection, and corporate governance. Journal of Finance, Vol. 63, 2737-2784.

Gigerenzer, G., Hoffrage, U., danKleinbolting, H.(1991). Probabilistic mental models: A Brunswikian theory of confidence. Psychological Review, 98, 506-528.

Hackbarth, D.(2008). Managerial traits and capital structure decisions. Journal of Financial Quantitative Analysis, Vol. 43, 843-881.

Haleblian, J., and Finkelstein, S. (1993). Top management team size, CEO dominance, and firm performance: The moderating roles of enviromental turbulence and discretion. Academy of Mangement Journal, Vol. 36, 844-863.

Hambrick, D., and Finkelstein, S. (1987). Managerial discretion: A bridge between polar views of organizational outcomes. Research in Organizational behaviour, Vol. 9,, 369-406.

Hambrick, D., and Mason, P. (1984). Upper ecchelon: The organization as reflection of its top manager. Academy of Management Review, Vol. 9, 193-206.

Hammond, J.S., Keeney, R.L., and Raiffa, H. (2006). The hidden traps in decision making. Harvard Business Review, Vol 84 (1), 120-126.

Hannan, M., and Freeman, J. (1977). The population ecology of organization. American Journal of Sociology, Vol. 82, 929-964.

Heaton, J.B. (2002). Managerial optimism and corporate finance. Financial Management, Vol. 31, 33-45.

Hirshleifer, D. (2001). Investor psychology and asset pricing. Journal of Finance, Vol. 56, 1533-1597.

Hoetker, G. (2007). The use of logit and probit model in strategic management research: Critical issues. Strategic Management Journal, Vol. 28, 331-343.

Huang, W., Jiang, F., Liu, Z., and Zhang, M. (2011). Agency cost, top executives' overconfidence, and investment-cash flow sensitivity - Evidence from listed company in China. Pacific-Basin Finance Journal, Vol. 19, 261-277.

Kahneman, D., and Tversky, A. (1982). The simulation heuristic. In D. Kahneman, $P$. Slovicdan A. Tversky (Eds.), Judgement under uncertainty: Heuristic and biases, (201-208). Cambridge, England: Cambridge University Press.

Kruger, J., and Dunning, D. (1999). Unskilled and unaware of it: How difficulties in recognizing one's own incompetence lead to inflated self-assessments. Journal of Social Psychology, Vol. 77, 1121-1134.

Langer, E.J. (1975). The ilussion of control. Journal of Personality and Social Psychology, Vol. 32, 311-328.

Li, J.T., and Tang, Y. (2010). CEO hubris and firm risk taking in China. Academy Management Journal, Vol 53 (1):45-69.

Lin, Y., Hu, S., and Chen, M. (2008). Testing pecking order prediction from the viewpoint of managerial optimism: Some empirical evidence from Taiwan. PacificBasin Finance Journal, Vol. 16, 160-181.

Lioukas, S., Bourantas, D., and Papadakis, V. (1993). Managerial autonomy of stateowned enterprises: Determining factors. Organization Science, Vol. 4, 645-666.

Malmendier, U., and Tate, G. (2005). CEOoverconfidence and corporate investment. Journal of Finance, Vol. 60, 2661-2700.

Malmendier, U., and Tate, G. (2005). Do overconfidence affects corporate invesment? CEO overconfidence measures revisited. European Financial Management, Vol. 11, No. 5: 649-659.

Malmendier, U., and Tate, G. (2008). Who makes acquisitions? CEOoverconfidence and the market's reaction. Journal of Financial Economics, Vol. 89, 20-43.

Malmendier, U., Tate, G., and Yan, J. (2011). Overconfidence and early-life experiences: the effect of managerial traits on corporate financial policies. Journal of Finance, Vol. 66, 168-173.

Moore, D.A., and Kim, T.G. (2003). Myopic social prediction and the solo comparison effect. Journal of Personality and Social Psychology, Vol. 85 (6), 1121-1135.

Richardson, S. (2006). Over-investment of free cash flow. Review of Accounting Studies, Vol. 11, 159-189

Schrand, C.M., and Zechman, S.L.C. (2012). Executive overconfidence and the 
slippery slope to financial missreporting. Journal of Accounting and Economics, Vol. 53, 311-329.

Shefrin, H. M. (2001). Behavioral corporate finance. Journal of Applied Corporate Finance, Vol 14 (3)

Svenson, O. (1981). Are we all less risky and more skillful than our fellow drivers?.ActaPsychologica, Vol. 47, 143148.
Tsui, A. (2007). From homogenization to pluralism: International management research in the academy and beyond. Acedemy of Management Journal, Vol. 50, 13531364..

Weinstein, N.D. (1980). Unrealistic optimism about future life events. Journal of Personality and Social Psychology, Vol. 39, 806-820.

Wu, C.H., and Liu, V.W. (2011). Payout policy and CEOoverconfidence. Working Paper. National Sun Yat-sen University, Taiwan. 